\title{
Teknik Rekonstruksi Turndown Flap Tendon Achilles dan Flap Fasiokutan Sural pada Ruptur Tendon Achilles yang Disertai Kerusakan Masif Jaringan Lunak: Laporan Kasus
}

\author{
Hermawan Nagar Rasyid, Andri Primadhi, Renaldi Prasetia \\ Departemen Orthopaedi dan Traumatologi Fakultas Kedokteran Universitas Padjadjaran \\ Rumah Sakit Dr. Hasan Sadikin Bandung
}

\begin{abstract}
Abstrak
Ruptur tendon achilles adalah cedera yang paling sering terjadi pada tendon ekstremitas bawah, meskipun merupakan tendon yang terbesar dan terkuat. Penelitian ini bertujuan menjelaskan teknik operasi dengan modifikasi augmentation pada penatalaksanaan ruptur tendon Achilles yang disertai kerusakan pada jaringan lunak yang luas. Kasus pada penelitian ini adalah seorang pasien (usia 30 tahun) dengan ruptur terbuka tendon Achilles akut dan terinfeksi, serta hilangnya tendon sampai dengan $5 \mathrm{~cm}$, kecacatan tendon yang tidak menempel di bagian distal dan hilangnya sebagian tulang calcaneus. Kerusakan kulit diukur setelah dilakukan debridemen dengan rentan antara $8 \mathrm{cmx} 5 \mathrm{~cm}$ sampai dengan $15 \mathrm{cmx} 10 \mathrm{~cm}$. Ruptur pada tendon dijahit dengan gastrosoleus turn down flap ke tulang calcaneus. Reverse sural artery digunakan untuk menutupi kulit. Flap yang dibuat berhasil hidup. Pasien dapat berjalan normal, dapat berdiri dengan ujung kaki, fleksi plantar yang aktif, dan dapat kembali beraktivitas dalam 2 bulan setelah operasi. Pasien memiliki rentang gerak penuh ke segala arah. Simpulan, debridemen, rekonstruksi tendon dalam satu tahap, dan reverse flow sural artery flap memberikan hasil yang memuaskan pada kasus robekan luas tendon Achilles dan kerusakan jaringan lunak yang luas. [MKB. 2016;48(1):58-62]
\end{abstract}

Kata kunci: Gastrosoleus turn down flap, ruptur, sural artery flap, tendon Achilles

\section{Achilles Tendon Turndown Flap Reconstruction and Fasciocutanous Sural Flap in Severe Tendon Achilles Loss with Massive Tissue Defect: a Case Report}

\begin{abstract}
Achilles tendon rupture is the most common ruptur of tendon in the lower limb despite being one of the toughest tendons. This rupture presents a complex problem to the treating surgeon especially if it is associated with tendon and soft tissue loss. The case in this study is one patient (male, age 30-year old) with a spectrum of acute and infected open tendon-achilles rupture that includes loss of tendon of up to $5 \mathrm{~cm}$, tendon defect with no distal attachment, and partial loss of the calcaneum. The skin defect measured after debridement ranged from $8 \times 5 \mathrm{~cm}$ to $15 \times 10 \mathrm{~cm}$. The ruptured tendon was sutured using gastrocnemius-soleus turn down flap technic to calcaneus bone. A reverse sural artery was used to provide soft tissue cover. The flap survived. The patient had normal gait, were able to stand on tip toes, had active plantar flexion, and had returned to his original occupation 2 months after reconstruction. He had full range of movement at the ankle. Augmented repair of Achilles tendon rupture with large soft tissue defect using gastrocnemius- soleus turn down flap and sural artery flap are stable enough to allow early weight-bearing with favorable clinical result for this patient. Conclusions is single stage tendon reconstruction and reverse flow sural artery flap give good functional outcome in complex Achilles tendon rupture with tendon and soft tissue loss. [MKB. 2016;48(1):58-62]
\end{abstract}

Key words: Achilles tendon, gastrocnemius-soleus turn down flap, rupture, sural artery flap

Korespondensi: Dr. Hermawan Nagar Rasyid, dr., Sp.OT(K), M.T (BME), Ph.D, Departemen Orthopaedi dan Traumatologi Fakultas Kedokteran Universitas Padjadjaran/Rumah Sakit Dr. Hasan Sadikin Bandung, Jalan Pasteur No. 38 Bandung, mobile 0811234001, e-mail hermawanphd@gmail.com 


\section{Pendahuluan}

Insiden ruptur tendon Achilles di negara maju telah meningkat dalam dua dekade terakhir. ${ }^{1}$ Meskipun sebagian besar tendon Achilles sobek (44\% sampai 83\%) terjadi selama kegiatan olahraga, struktural, biokimia, dan biomekanik perubahan intrinsik terkait dengan penuaan dapat memainkan peran penting. . $^{2}$

Ruptur tendon Achilles ialah cedera yang paling sering terjadi pada tendon ekstremitas bawah, meskipun merupakan tendon yang terbesar dan terkuat. Kejadian ruptur tersebut merupakan masalah yang cukup rumit untuk para spesialis orthopaedi yang menanganinya terutama apabila kasus ruptur yang disertai dengan bagian tendon dan juga jaringan lunak yang telah menghilang. Ruptur tendon Achilles lebih sering terjadi pada laki-laki dengan rasio laki-perempuan 1,7:1 sampai 30:1, mungkin prevalensi yang lebih besar dari partisipasi olahraga laki-laki ataupun kerentanan mereka terhadap cedera. Biasanya, cedera akut tendon Achilles terjadi pada laki-laki atau para pekerja profesional yang pada minggu ketiga/keempat kadang-kadang bermain olahraga (akhir pekan).

Penatalaksanaan ruptur pada tendon Achilles secara nonoperatif dan operatif. Nonoperatif menggunakan plaster cast atau splint selama 6-8 minggu. Penanganan secara operatif dengan modifikasi augmentation, yaitu penanganan ruptur tendon Achilles dengan gastrocnemiussoleus turn down flap dan reverse flow sural artery flap untuk menutupi kulitnya. Penelitian ini bertujuan menjelaskan teknik operasi dengan modifikasi augmentation pada penatalaksanaan ruptur tendon Achilles yang disertai kerusakan pada jaringan lunak.

\section{Laporan Kasus}

Seorang pasien Tn. D, usia 30 tahun, datang ke IGD Rumah Sakit Dr. Hasan Sadikin Bandung (RSHS) Desember 2014 dengan keluhan nyeri dan luka terbuka, dengan ruptur pada tendon Achilles dan terinfeksi, disertai hilangnya tendon sampai dengan $5 \mathrm{~cm}$, dan hilangnya sebagian tulang calcaneus pada kaki kanan. Dilakukan tes Thompson dengan hasil tes negatif. Pasien menolak untuk dilakukan tindakan di kamar operasi dan hanya ingin dijahit lukanya di IGD tanpa dilakukan penjahitan tendon Achilles. Setelah lima hari, pasien tersebut datang dengan keluhan luka yang terinfeksi (Gambar 1). Lalu pasien dirawat untuk direncanakan tindakan

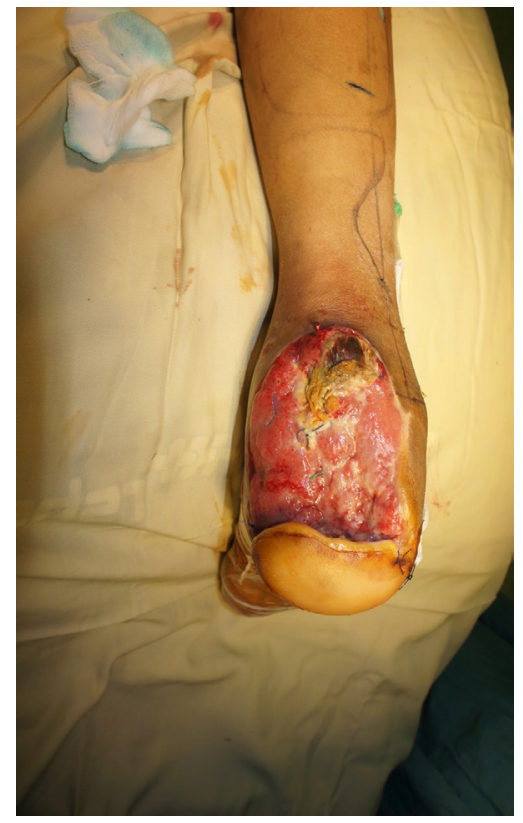

\section{Gambar 1 Defek Luka pada Tumit}

debridemen disertai rekonstruksi pada tendon Achilles dan jaringan lunak dengan menggunakan prosedur reverse flow fasciocutaneous sural flap.

\section{Teknik Operasi}

Perencanaan preoperatif memperhatikan usia, jenis kelamin pasien, ukuran dan letak defek jaringan, terpaparnya jaringan tulang serta tendon, ada atau tidaknya osteomielitis, dan juga faktor-faktor komorbiditas lainnya. Perencanaan perioperatif sangat memperhatikan dimensi dari flap, batas proksimal flap, jaringan donor yang akan dilakukan flap, proses pembuatan tunnel pedikel, refill kapiler, ada atau tidaknya kongesti pada pembuluh darah sebelum, saat prosedur flap fasiokutan yang dilakukan, serta viabilitas dan luas tendon Achilles. Pada perencanaan postoperatif dilakukan monitoring warna flap dan ada tidaknya kongesti vena. Fungsi dan estetika akan dievaluasi setelah flap bertahan secara parsial dan komplet. Evaluasi kesuksesan penutupan defek pada area donor dan resipien, proses penyembuhan tulang dibuktikan secara radiologis dan kemampuan untuk melakukan pergerakan pada sendi pergelangan kaki yang dilakukan pada dua bulan setelah prosedur telah dilakukan.

Setelah dilakukan tindakan anastesi dan juga pemasangan torniket pada bagian paha pasien. Pasien diposisikan pronasi. Dilakukan 


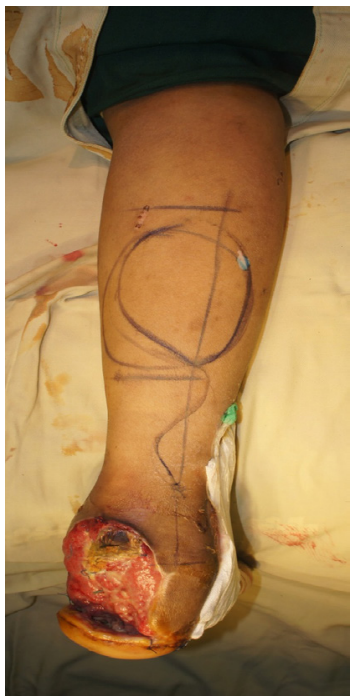

\section{Gambar 2 Perencanaan Garis Insisi Prosedur Operasi}

penandaan daerah yang akan diinsisi. Penandaan garis insisi dimulai dengan titik antara maleolus lateral dan tendon Achilles (Gambar 2). Garis insisi diperpanjang ke proksimal sampai batas antara sepertiga proksimal dan dua pertiga distal dari panjang posterior tungkai bawah.Pembuluh perforator dari arteri peroneal terdistal terletak pada $5 \mathrm{~cm}$ dari ujung maleolus lateral. Kemudian beberapa sentimeter distal dari fosa poplitea dilakukan penandaan luas jaringan kulit dan fasia yang akan ditandur untuk menutupi luka defek. Dilakukan debridemen untuk menghilangkan jaringan yang terlihat tidak sehat atau terinfeksi, dan memperjelas luas area defek yang akan dilakukan penutupan dengan flap. Dilakukan insisi posterolateral curvilinear untuk kulit, insisi longitudinal jaringan subkutaneus dari calcaneus sampai sepertiga tengah. Lalu, diinsisi secara longitudinal paratenon dari tendon Achilles. Insisi pada gastrocnemius sepanjang $9 \mathrm{~cm}$ dari distal ke arah proksimal dengan lebar $2 \mathrm{~cm}$ (1/3 tengah dari seluruh lebar tendon Achilles (Gambar 3). Kemudian, dilakukan pemasangan anchor pada sisa tuberositas calcaneus (Gambar 3). Flap turndown bagian sepertiga tengah tendon Achilles dilakukan disertai penjahitan memakai teknik Krackow. Dilanjutkan dengan augmentasi longitudinal menggunakan tendon plantaris yang diinterposisikan dengan fashion spiral.

Tahap kedua, adalah melakukan tindakan flap fasiokutan sural. Jaringan kulit tersebut diinsisi sirkumferensial sampai lapisan dermis. Jaringan neurovaskular sural dan vena safena brevis diidentifikasi dan diligasi. Flap diangkat sampai 5 $\mathrm{cm}$ bagian proksimal dari ujung maleolus lateral untuk menjaga perfusi dari pembuluh perforator dari arteri peroneal. Lebar pedikel (jaringan lemak dan subkutaneus) dipertahankan sebesar $4 \mathrm{~cm}$ untuk menjamin keutuhan dari jaringan neurovaskular sural. Flap itu di-imobilisasikan dengan hati-hati untuk menutupi defek jaringan pada daerah tumit. Setelah itu, dilakukan insisi dan pembebasan jaringan sekitar pada jembatan kulit di distal tempat berputarnya flap untuk menghindari penekanan pada pedikel (Gambar 4). Area pedikel direncanakan untuk dilakukan split thickness skin graft atau STSG setelah keberhasilan flap dipastikan. Posisi pergelangan kaki dipertahakan plantigrade dengan memakai 2 buah Schanz screw untuk memfiksasi sendi tibiotalar yang akan dilepas 3 minggu kemudian, dilanjutkan dengan latihan pergerakan sendi pergelangan kaki.
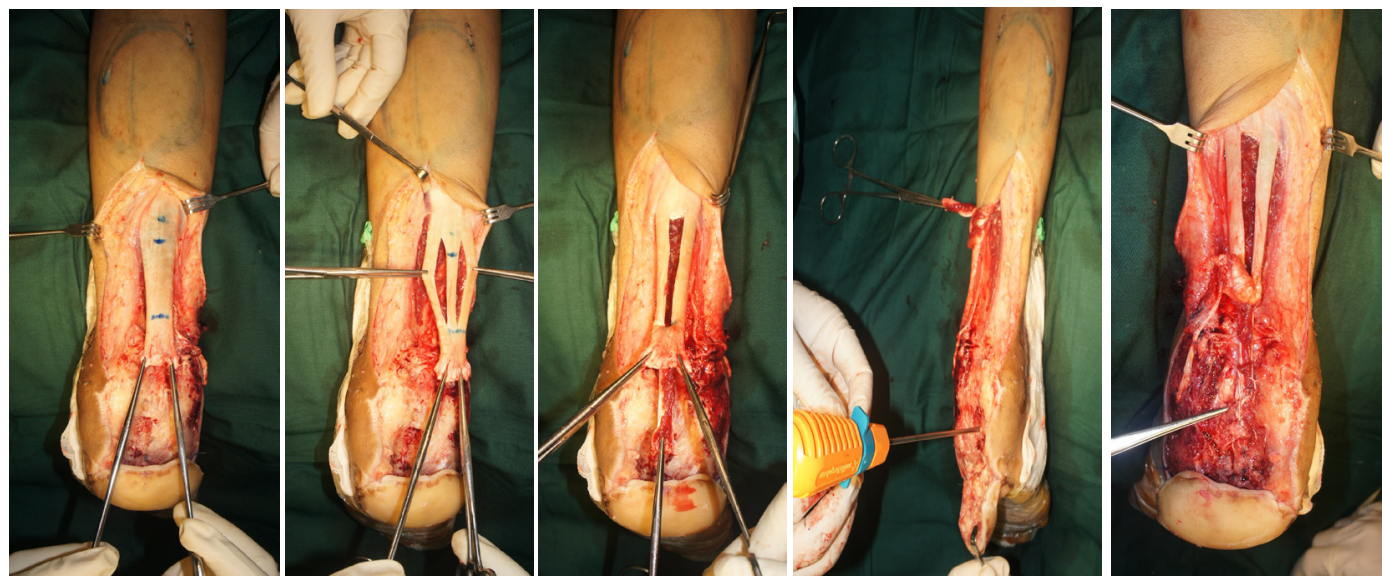

Gambar 3 Turn down Achilles Tendon Flap dan Anchoring 

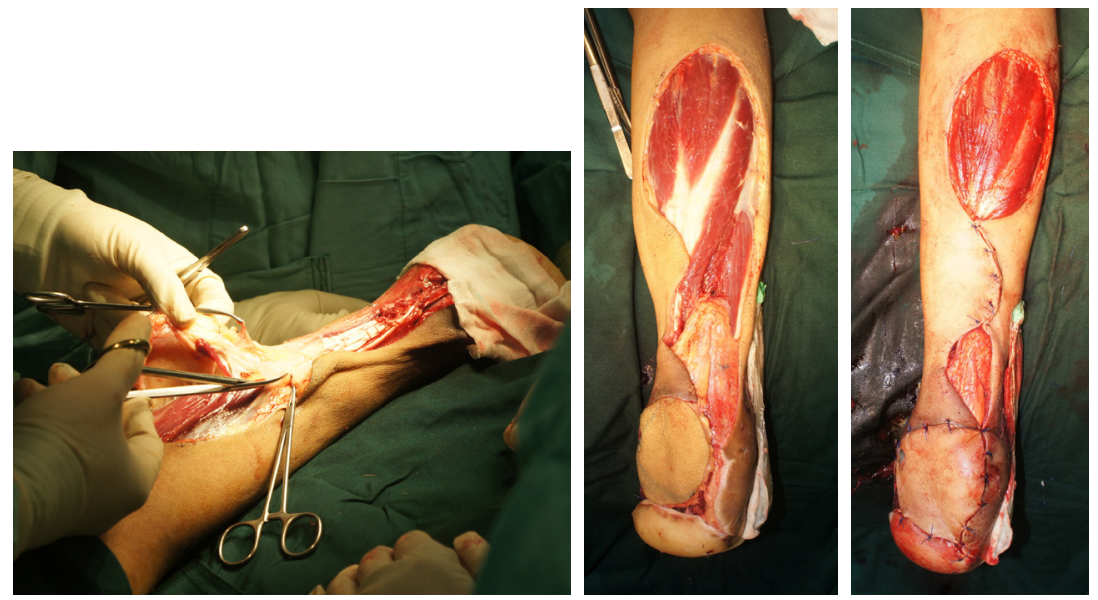

\section{Gambar 4 Reverse Flow Sural Fasciocutaneous Flap}

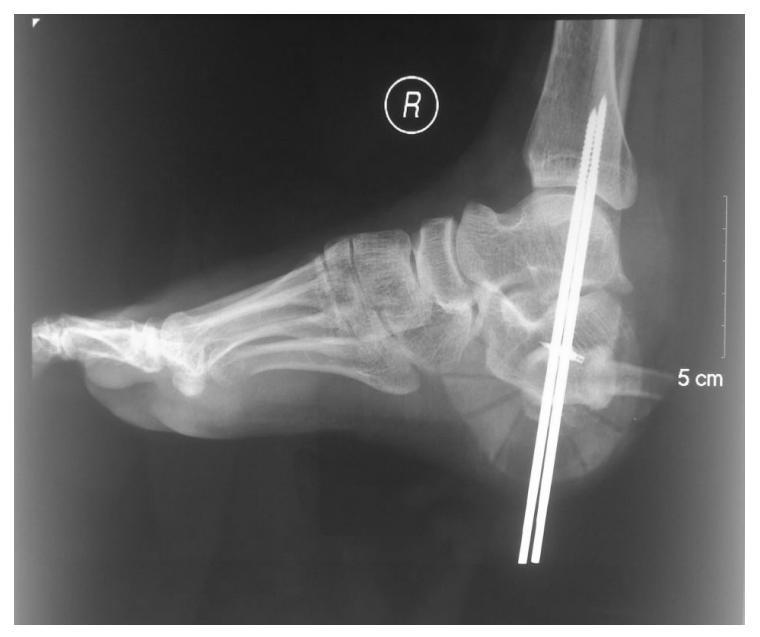

Gambar $5 X$-Ray Postoperasi
Hasil

Flap yang dibuat berhasil hidup. Pasien dapat berjalan normal, dapat berdiri dengan ujung kaki, fleksi plantar yang aktif, dan dapat kembali beraktivitas dalam 2 bulan setelah operasi. Pasien memiliki rentang gerak penuh ke segala arah (Gambar 5 dan 6).

\section{Pembahasan}

Beberapa teknik operasi dapat dipergunakan untuk melakukan perbaikan pada robekan tendon Achilles. Penentuan teknik yang paling sesuai dipengaruhi oleh tipe dan juga ukuran robekan. Robekan tendon Achilles tanpa disertai kehilangan jaringan yang luas dapat diperbaiki dengan metode penjahitan per kutan, modifikasi
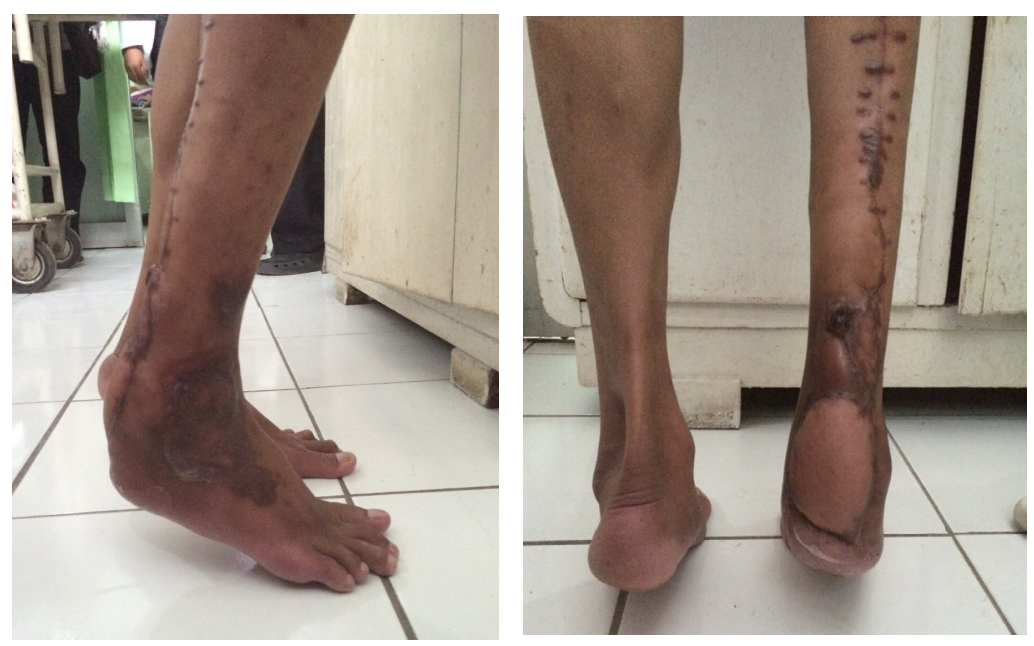

Gambar 6 Fungsi Pergelangan Kaki Setelah 2 Bulan Prosedur Operasi 
Kessler, Bunnel, dan Krackow. Pasien yang kami tangani memiliki hilangnya tendon sampaidengan $5 \mathrm{~cm}$ dan hilangnya sebagian tulang calcaneus pada kaki kanan. Penatalaksanaan tendon Achilles dengan kehilangan jaringan yang luas memerlukan jaringan baru atau bahan sintetik untuk dapat menghubungkan ujung sisa tendon dengan daerah insersi pada tulang calcaneus. Alternatif teknik yang dapat dilakukan adalah teknik Lindholm, teknik Bosworth, dan teknik perbaikan V-Y.,4 Penatalaksanaan pada pasien kami berbeda dengan teknik Bosworth. Kami melakukan harvest pada bagian sentral dari tendon Achilles dengan seluruh ketebalan tendon donor. Ukuran yang dipersiapkan adalah $9 \mathrm{~cm} \times 2 \mathrm{~cm}$, dengan acuan $2 \mathrm{~cm}$ adalah titik putar tendon donor, panjang $5 \mathrm{~cm}$ adalah besar celah yang harus ditutupi, dan panjang $2 \mathrm{~cm}$ adalah besar tendon donor yang berinsersi dengan tulang calcaneus. Celah yang ditinggalkan tendon donor kami tutup dengan melakukan penjahitan interrupted bagian medial dan lateral tendon Achilles. Perlekatan tulang calcaneus difasilitasi dengan menggunakan dua buah anchor. Setelah itu, dilakukan modifikasi metode Lynn dengan melakukan augmentasi spiral mempergunakan tendon plantaris pada flap tendon Achilles. Kami tidak melakukan fanning pada tendon plantaris karena prosedur tersebut dapat menghilangkan kekuatan longitudinal tendon plantaris sehingga akan mengurangi kekuatan augmentasi. ${ }^{5,6}$

Permasalahan kedua di dalam penanganan pasien ini adalah defek kulit yang luas. Teknik penutupan defek dengan flap diharapkan dapat digunakan untuk meyelesaikan permasalahan ini. Flap dapat menutup pembuluh darah, tendon, dan tulang. ${ }^{7,8}$ Flap fasiokutan sural dengan titik putar di bagian distal dapat digunakan untuk kasus-kasus serupa. ${ }^{9}$ Arteri peroneal, arteri tibialis anterior/posterior yang tersumbat, dan verikosa pada sistem vena safena merupakan kontraindikasi absolut untuk tindakan flap ini. Komplikasi tindakan flap ini antara lain nekrosis parsial (8\%), nekrosis marginal (8\%), dan nekrosis total (4\%). Suatu penelitian metaanalisis menyatakan bahwa angka keberhasilan flap sural mencapai 82\%.,10 Beberapa teknik dapat dipergunakan untuk meningkatkan aliran perfusi pada flap fasiokutaneus sural, antara lain menjaga lebar pedikel sekurangnya $4 \mathrm{~cm}$, mengikutsertakan sedikit otot gastrocnemius jika flap digunakan untuk menutupi area yang luas dan sangat distal. ${ }^{11,12}$

Simpulan, kasus ini adalah penatalaksanaan kasus ruptur tendon Achilles dengan bagian tendon dan jaringan lunak yang menghilang, debridemen, serta rekonstruksi tendon dengan turn-down Achilles flap dan reverse flow sural artery flap memberikan hasil yang memuaskan. Metode ini memberikan hasil yang konsisten pada kasus ruptur tendon Achilles terbuka.

\section{Daftar Pustaka}

1. Hess GW . Achilles tendon rupture: a review of etiology, population, anatomy, risk factors, and injury prevention. Foot Ankle Spec. 2010;3(1):29-32.

2. Cary DV. How to diagnose and manage an acute Achilles tendon rupture. JAAPA. 2009;22(8):39-43.

3. Hadi M, Young J, Cooper L, Costa M, Maffulli N. Surgical management of chronic ruptures of the Achilles tendon remains unclear: a systematic review of the management options. Br Med Bull. 2013;108(1):95-114.

4. Maffulli N, Ajis A. Management of chronic ruptures of the Achilles tendon. J Bone Joint Surg Am. 2008;90(6):1348-60.

5. Ibrahim SA. Surgical treatment of chronic Achilles tendon rupture. J Foot Ankle Surg. 2009;48(3):340-6.

6. Akhtar S, Hameed A. Versatility of the sural fasiocutaneous flap in the coverage of lower third leg and hind foot defects. J Plast Reconstr Aesthet Surg. 2006;59(8):839-45.

7. Foran MP, Schreiber J, Christy MR, Goldberg NH, Silverman RP. The modified reverse sural artery flap for lower extremity reconstruction. J Trauma. 2008;64(1):13943.

8. Follmar KE, Baccarani A, Steffen P, Baumeister L, Levin S, Erdmann D. The distally based sural flap. Plast Reconstr Surg. 2007;119(6):138-48.

9. Chen SL, Chen TM, Wang HJ. The distally based sural fasciomusculocutaneous flap for foot reconstruction. J Plast Reconstr Aesthet Surg. 2006;59(8):846-55.

10. Al-Qattan MM. The reverse sural artery fasciomusculocutaneous flap for small lowerlimb defects: the use of the gastrocnemius muscle cuff as a plug for small bony defects following debridement of infected/necrotic bone. Ann Plast Surg. 2007;59(3):307-10.

11. Al-Qattan MM. The reverse sural fasciomusculocutaneous "mega-high" flap: a study of 20 consecutive flaps for lower-limb reconstruction. Ann Plast Surg. 2007;58(5): 513-6. 